\title{
Influence of Mycorrhization during the Hardening Process of Micropropagated Plants
}

\author{
M. Cantos ${ }^{1, \text { a }}$, J. Liñán ${ }^{1}$, C.L. Carretero ${ }^{1}$, A. Troncoso ${ }^{1}$ and R. Azcón ${ }^{2}$ \\ ${ }^{1}$ Instituto de Recursos Naturales y Agrobiología de Sevilla (CSIC), Sevilla, Spain \\ ${ }^{2}$ Estación Experimental del Zaidín, CSIC, Granada, Spain
}

Keywords: acclimatization, cassava, Glomus intraradices, grape, olive

\begin{abstract}
This work aims to know the effect of the Glomus intraradices fungus substratum inoculation on the survival, development and nutritive status of cassava, grape and olive plants during hardening. Micropropagated plants of cassava, grape and olive were transplanted individually to $2 \mathrm{~L}$ pots filled half of them with steamy sterilized soil and the other half with the same soil inoculated with Glomus intraradices fungus. The potted plants were placed in a culture chamber and irrigated only with tap water, maintaining field capacity. The number of dead plants, stem plus shoots growth, fresh and dry weight and nutritive status of mycorrhized and non mycorrhized plants of each species were recorded at 60 days for cassava, 30 days for grape and 180 days for olive. Presence of the fungus in the roots of each plant species was checked by staining with trypan blue. Due to the high survival percentage of the control plants, non significant differences between the survival of the control and mycorrhizal cassava and grape plants were found. On the contrary, there was a beneficial effect of mycorrhizal on olive plant surviving. With the differences due to time (days from transplanting) and plant species, in all cases mycorrhizal significantly improved aerial plant growth and biomass production. Mycorrhizal only affected positively the relative content of $P$ in both cassava and olive plants, and $\mathrm{Fe}$ in olive. Considering the bigger biomass of the mycorrhized plants the total amount of each nutrient was higher in these plants. All the mycorrhizal plants responded positively to trypan blue treatment.
\end{abstract}

\section{INTRODUCTION}

Micropropagated plants are characterized by a bad control of foliar transpiration and not fully operative roots to hold up in vitro-ex vitro transplanting.

Together to relative humidity control (Cantos et al., 1993) arbuscular mycorrhizas are a very effective tool to increase plant survival and development during hardening (Lovato et al., 1996; Naqvi and Mukerji, 1998; Vasane and Kothari, 2006). For that this work aims to know the effect of the Glomus intraradices fungus substratum inoculation on the survival, development and nutritive status during the hardening of micropropagated cassava, grape and olive plants.

\section{MATERIALS AND METHODS}

Physical and chemical characteristics of the soil (Table 1) were determined as follows: it was air dried, crushed and sieved through $2 \mathrm{~mm}$ mesh and the following parameters determined: texture (Bouyoucus methods), $\mathrm{pH}$ (in saturated paste extract), carbonate (Bernard calcimeter), organic matter (Walkley and Black method), N (Kjeldahl method), extractable P (Olsen method), available K (flame photometer) available $\mathrm{Ca}$ and $\mathrm{Mg}$ and $\mathrm{Fe}$ (plasma emission technique).

Micropropagated plants of cassava (288), 110R grape-vine root-stock (24) and cv. Manzanillo olive (32) were transplanted individually to $2 \mathrm{~L}$ pots filled half of them with steamy sterilized soil (Table 1) and the other half with the same soil inoculated with Glomus intraradices fungus (isolate 11AG8903). Micorrhizal inoculum was provided by R. Azcón (E.E. "Zaidin", CSIC, Granada, Spain) and consisted in a mixed rhizosphere 
samples containing spores, hypha and mycorrhizal root fragments. Twenty grams of inoculum were added to each pot. The potted plants were placed in a culture chamber and irrigated only with tap water, maintaining field capacity. The number of dead plants, stem plus shoots growth, fresh and dry weight and nutritive status of the mycorrhized and non mycorrhized plants of each species were recorded at 60 days for cassava, 30 days for grape and 180 days for olive (grape plants were not analysed because the experiment is still on progress). Determination of N was by Kjeldahl (Jackson, 1962), P by colorimetric methods, and $\mathrm{K}, \mathrm{Ca}, \mathrm{Mg}, \mathrm{Fe}, \mathrm{Mn}, \mathrm{Cu}, \mathrm{Zn}$, and $\mathrm{B}$ by plasma emission techniques (Hamilton, 1980).

Presence of the fungus in the roots of each plant species was checked by staining with trypan blue (Phillips and Hayman, 1970). Student's t test (Fig. 1 and Tables 2 and 3) and multifactor analysis of variance (Fig. 2) were used for statistical analysis.

\section{RESULTS AND DISCUSSION}

Some soil-substratum characteristics are shown in Table 1. According to texture the soil can be defined as a sandy soil. The soil used as substratum is a low fertility soil, which is an advantageous condition for mycorrhizal effects.

There exist no significant differences in the after transplanting survival between the mycorrhizal and non mycorrhizal cassava and grape plants, due to the high percent of survival in the non mycorrhizal plants (Fig. 1). This high level of survival after the in vitro-ex vitro transplanting of non mycorrhizal plants was also obtained by Carretero et al. (2001) with cassava and by Cantos et al. (1993) with grape, indicating their high tolerance to the in vitro-ex vitro transplanting stress. On the contrary, the number of losses after the in vitro-ex vitro transplanting of olive plants was higher (Fig. 1) (Troncoso et al., 2004 also indicated these results). In this case a significant increase of the mycorrhizal plants survival was observed (Fig. 1). Consequently, there is a beneficial effect of mycorrhizal on the survival of olive plants and it could be interesting for the in vitro-ex vitro transplanting of other species.

With the differences due to time (days from transplanting) necessary for symbiosis development and species response, mycorrhizal established beneficial differences on the aerial plant growth (Fig. 2): These differences were very low for grape plants due to the short time (30 days) elapsed from mycorrhization while olive plants presented the highest differences after 180 days from inoculation.

The positive effect of mycorrhizal was also showed in the biomass plant production (Table 2). As in aerial plant growth existed a clear influence of time and species. With grape plants (only 30 days from fungus application) there are no differences between mycorrhized and non mycorrhized plants. Cassava plants with less time of fungus inoculation than olive plants showed the greatest differences indicating the mycorrhizal dependence of this species (Sieverding, 1991; Azcón-Aguilar et al., 1997).

In relation to plant nutritive status, mycorrhizal only affected positively the percentage (relative content) of $\mathrm{P}$ (Table 3 ) both cassava and olive plants and $\mathrm{Fe}$ in olive, but considering the biomass production or plant growth of the mycorrhizal plants the total amount of each nutrient (absolute content) was much higher in the mycorrhizal plants, indicating a greater absorption from the substratum.

Then mycorrhizal favoured plant survival, growth, biomass production and nutrition during the hardening period after in vitro-ex vitro transplanting and this is interesting in the in vitro plant propagation works. All the mycorrhizal plant-roots treated with trypan-blue show the presence of the Glomus intraradices and in relation with the time from fungus application.

\section{Literature Cited}

Azcón-Aguilar, C., Troncoso, A., Cantos, M. and Barea, J.M. 1997. Beneficial effect of arbuscular mycorrhizas on acclimatization of micropropagated cassava plantlets. Scientia Hort. 72(1):63-71.

Bouyoucos, G.J. 1927. The hydrometer as a new method for the mechanical analysis of 
soils. Soil Sci. 23:343-350.

Cantos, M., Liñán, J., Pérez-Camacho, F. and Troncoso, A. 1993. Obtención de plantas selectas de vid, variedad Zalema, libres de virosis entrenudo corto. Actas de Horticultura 1:705-709.

Carretero, C.L., Cantos, M. and Troncoso, A. 2001. Influencia de micorrizas vesículoarbusculares sobre el desarrollo in vitro y ex vitro de plantas de mandioca. XIV Reunión de la Sociedad Española d Fisiología Vegetal y VII Congreso Hispano-Luso de Fisiología Vegetal. Badajoz, Spain 23-27 Sept.

Hamilton, E.I. 1980. Analysis for trace elements II. Instrumental analysis. In: B.E. Davies (eds.), Applied soil trace elements. Chichester.

Jackson, M.L. 1962. Soil chemical analysis, Constable and Co. Ltd. London.

Lovato, P.E., Gianinazzi-Pearson, V., Trouvelot, A. and Gianinazzi, S. 1996. The state of art of mycorrhiza and micropropagation. Adv. Hort. Sci. 1:46-52.

Naqvi, N.S. and Mukerji, K.G. 1998. Mycorrhization of micropropagated Leucaena leucocephala (Lam.) de Wit. Symbiosis 24(1):103-113.

Olsen, S.R. 1972. Micronutrient interactions. In: Micronutrient in agriculture. Ed Soil Sci. Soc, Amer. Inc., Madison/Wisconsin.

Phillips, J.M. and Hayman, D.S. 1970. Improved procedure for clearing roots and staining parasitic and vesicular-arbuscular mycorrhizal fungi for rapid assessment of infection. Transactions of the British Mycological Society, 55, 158.

Sieverding, E. 1991. Vesicular-arbuscular mycorrhiza management in tropical agrosystems. Deutsche Gesellschaft Technische Zusammenarbeit (GZT), Eschborn, Germany.

Troncoso, J., Liñán, J., Cantos, M., García, J.L., Troncoso, A. and Carretero, C.L. 2004. Influence of the mycorrhizal Glomus intraradices on the development of in vitro raised olive seedlings during acclimation phase. Proc. $5^{\text {th }}$. International Symposium on Olive Growing. ISHS. Izmir. Turquía. 27 Sept.-2 Oct.

Vasane, S.R. and Kothari, R.M. 2006. Optimisation of secondary hardening process of banana plantlets (Musa paradisiaca L. var. grand nain). Indian Journal of Biotechnology 5(3)394.

Walkley, A. and Black, I.A. 1934. An examination of the Degtjareff method for determining soil organic matter and a proposed modification of the chromic acid tritation method. Soil. Sci. 37:29-38.

\section{$\underline{\text { Tables }}$}

Table 1. Characteristics of the soil used as substratum.

\begin{tabular}{|c|c|c|c|c|c|c|c|c|c|}
\hline \multicolumn{4}{|c|}{ Texture } & \multirow{2}{*}{$\begin{array}{c}\mathrm{CaCO}_{3} \\
(\%)\end{array}$} & \multirow{2}{*}{$\begin{array}{c}\text { Organic matter } \\
(\%)\end{array}$} & \multirow{2}{*}{$\begin{array}{c}\mathrm{N} \\
(\%)\end{array}$} & \multirow[t]{2}{*}{$\mathrm{P}$} & \multirow{2}{*}{\multicolumn{2}{|c|}{ K $\underset{\left(\mathrm{mg} \mathrm{kg}^{-1}\right)}{\mathrm{Ca}} \mathrm{Mg}$}} \\
\hline $\begin{array}{c}\text { Sand } \\
(\%)\end{array}$ & $\begin{array}{c}\text { Loam } \\
(\%)\end{array}$ & $\begin{array}{c}\text { Clay } \\
(\%)\end{array}$ & $\mathrm{pH}$ & & & & & & \\
\hline 76 & 8 & 16 & 7 & 1 & 0.8 & 0.03 & 16 & 199 & 113 \\
\hline
\end{tabular}


Table 2. Influence on the biomass production (cassava, 60 days; grape 30 days; olive 180 days).

\begin{tabular}{lcccccc}
\hline Weight & \multicolumn{2}{c}{ Cassava } & \multicolumn{2}{c}{ Grape } & \multicolumn{2}{c}{ Olive } \\
\cline { 2 - 6 }$(\mathrm{mg})$ & Non & Myc. & Non & Myc. & Non & Myc. \\
\hline Fresh & $1236 \mathrm{a}$ & $15178 \mathrm{~b}$ & $511 \mathrm{a}$ & $556 \mathrm{a}$ & $6031 \mathrm{a}$ & $18100 \mathrm{~b}$ \\
Dry & $285 \mathrm{a}$ & $2994 \mathrm{~b}$ & $109 \mathrm{a}$ & $116 \mathrm{a}$ & $2605 \mathrm{a}$ & $7200 \mathrm{~b}$ \\
\hline
\end{tabular}

Different letters in rows indicate significance at the $\mathrm{p} \leq 0.01$ level among control and mycorrhizal plants.

Table 3. Influence on the plant nutritive status.

\begin{tabular}{lcccccccccc}
\hline Plant & \multicolumn{9}{c}{$\mathrm{dw}(\%)$} & \multicolumn{1}{c}{ ppm } \\
\cline { 2 - 12 } & $\mathrm{N}$ & $\mathrm{P}$ & $\mathrm{K}$ & $\mathrm{Ca}$ & $\mathrm{Mg}$ & $\mathrm{Fe}$ & $\mathrm{Mn}$ & $\mathrm{Cu}$ & $\mathrm{Zn}$ & $\mathrm{B}$ \\
\hline Cassava & & & & & & & & & & - \\
Non Myc. & $4.21 \mathrm{a}$ & $0.14 \mathrm{a}$ & $1.89 \mathrm{a}$ & $2.07 \mathrm{a}$ & $0.38 \mathrm{a}$ & - & - & - & - & - \\
Myc. & $3.48 \mathrm{a}$ & $0.2 \mathrm{~b}$ & $2.06 \mathrm{a}$ & $2.82 \mathrm{a}$ & $0.40 \mathrm{a}$ & - & - & - & - & - \\
\hline Olive & & & & & & & & & & \\
Non Myc. & $1.66 \mathrm{a}$ & $0.04 \mathrm{a}$ & $0.77 \mathrm{a}$ & $0.86 \mathrm{a}$ & $0.15 \mathrm{a}$ & $558 \mathrm{a}$ & $66 \mathrm{a}$ & $16 \mathrm{a}$ & $11 \mathrm{a}$ & $17 \mathrm{a}$ \\
Myc. & $1.46 \mathrm{a}$ & $0.1 \mathrm{~b}$ & $0.78 \mathrm{a}$ & $0.85 \mathrm{a}$ & $0.15 \mathrm{a}$ & $1023 \mathrm{~b}$ & $48 \mathrm{a}$ & $22 \mathrm{a}$ & $10 \mathrm{a}$ & $15 \mathrm{a}$ \\
\hline
\end{tabular}

Different letters in columns (in the same species) indicate significance at the $\mathrm{p} \leq 0.01$ level among control and mycorrhizal plants.

\section{$\underline{\text { Figures }}$}

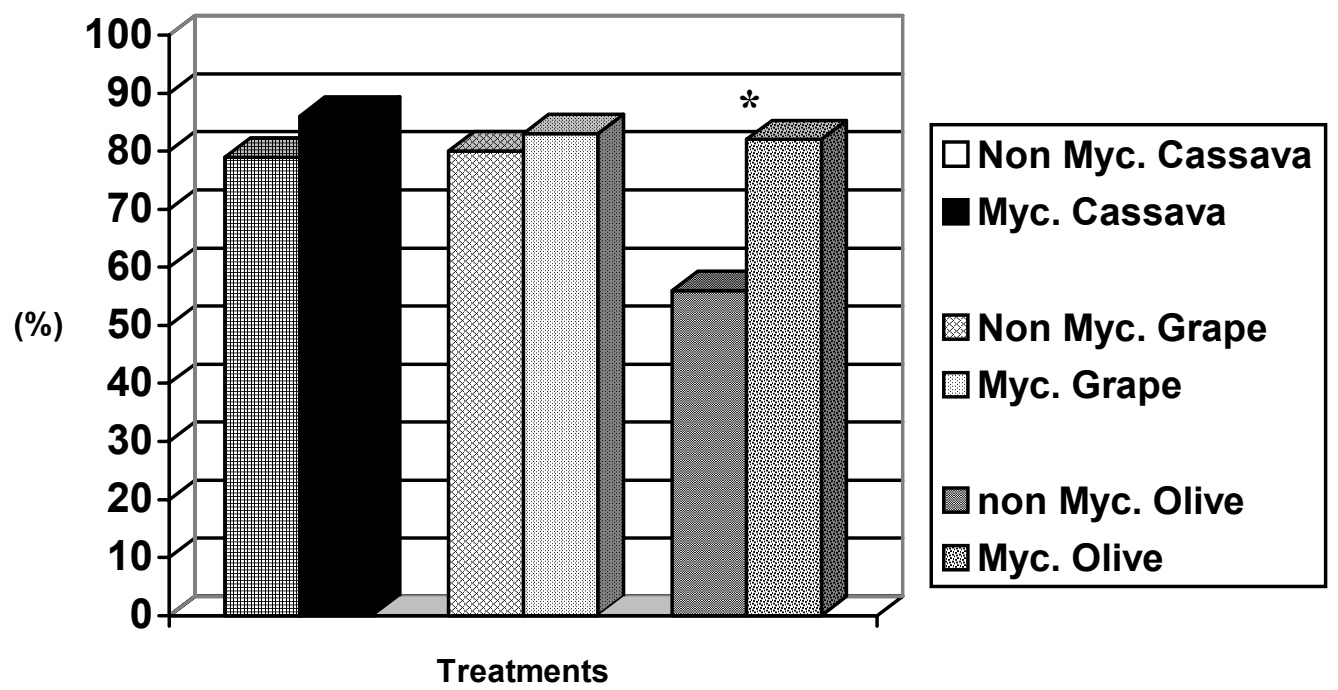

Fig. 1. Influence on plants surviving after 20 days from the transplanting. 


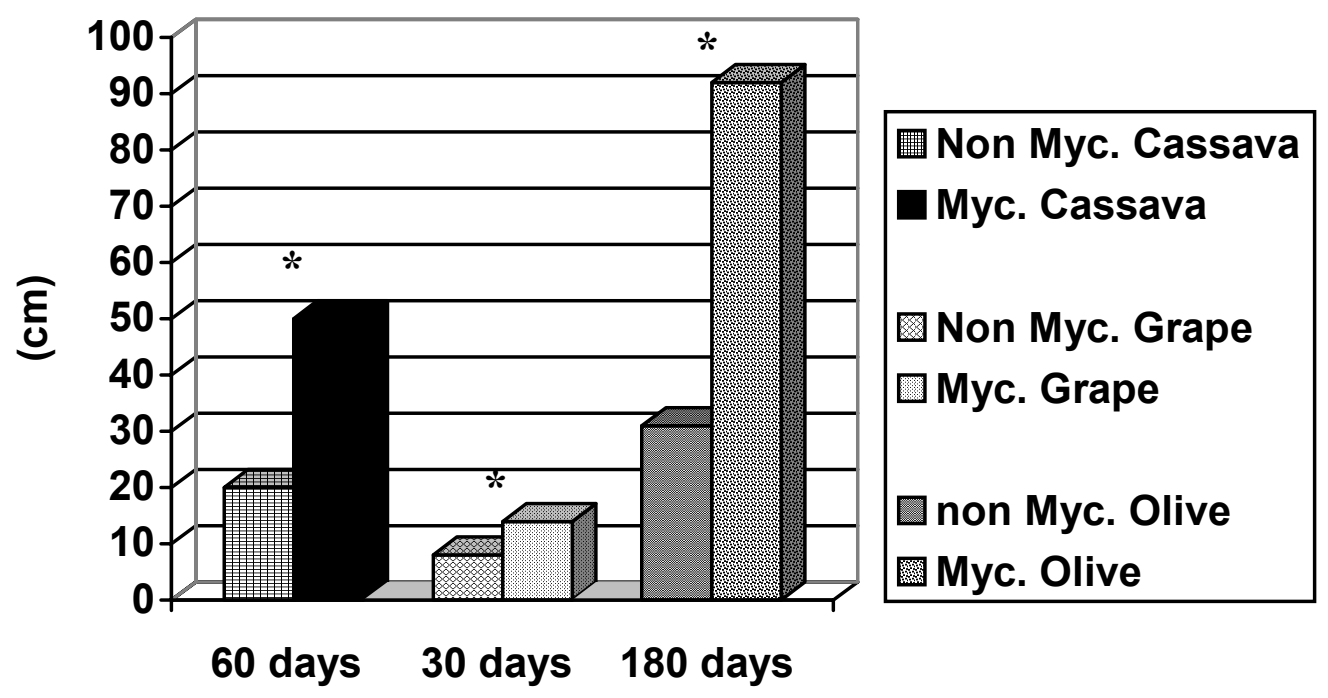

Fig. 2. Influence on the stem and shoots growth (addition). 